\title{
Sex in Asian Cinema
}

\author{
By Toh, Hai Leong
}

\section{Fall 2000 Issue of KINEMA}

IN JAPAN, the euphemistic term for the sex cinema is "pink films" (pinku-eiga) or "roman poruno" (romance pornography) while the Filipinos call it "bomba". In pre-and-post-1997 Hong Kong, sex films are rated and popularly known as Category III (adult audience only). No matter how sex films are termed, this genre still raises a lot of ire, from the censors as well as from the public. Last year, many film productions in the Philippines were suspended for fear of more censorship.

The promise of naked flesh and the chimera of sexual release has always made the appetite for this genre insatiable. Yet the more interesting films have posed complex emotional, psychological and existential questions. For instance, the male fear of emasculation was seen in the breakthrough "hardcore" sex film, Nagisa Oshima's Ai no corrida (In The Realm Of The Senses, 1976), based on a true story in Tokyo in 1936, when a woman was found wandering in the street with her lover's severed penis in her hand. He had allowed himself to be strangled and mutilated in a final ecstasy of sexual pleasure. Oshima followed up with Ai no borei (Empire of Passion aka The Ghost of Love, 1978), an equally powerful, if less explicit, tale of an adulterous couple who kill an old rickshaw puller and whose ghost returns to haunt them.

One recurrent theme of sex erotica, be they Japanese, Korean, Hong Kong, Chinese, Philippines or Taiwanese, is the motif of death, especially when incest, brutal gang rapes or adultery are involved. There also seems to be a "morality clause" - as if divine retribution would rain down on this most basic and powerful crime of passion.

In the Hong Kong film, Daughter of Darkness, Lily Chung is raped by her womanising stepfather, and exacts revenge by killing him and the rest of her siblings. The Taiwanese film, Zeng Zhuang Xiang's The Woman of Wrath, depicts Pat Ha as a wife who is brutalised by her boorish husband. When she cannot tolerate his violent rapes anymore, she murders him in his sleep. The late Li Han Xiang, master of the chamber film, remade The Golden Lotus twice in his lifetime - based on the famous story of the exploits of Wu-sung, a morally upright fighter who avenges the murder of his handicapped older brother by killing the adulterous couple, Jin Ping Mei and her seducer-lover, Xi Men Qing. The first version was made in the 1960s and the second version in the late 1970s. Director Li followed the adultery portion of the literary text, with the twin theme of sex and death, to "moralise" and instruct on the evils of lust, murder and adultery.

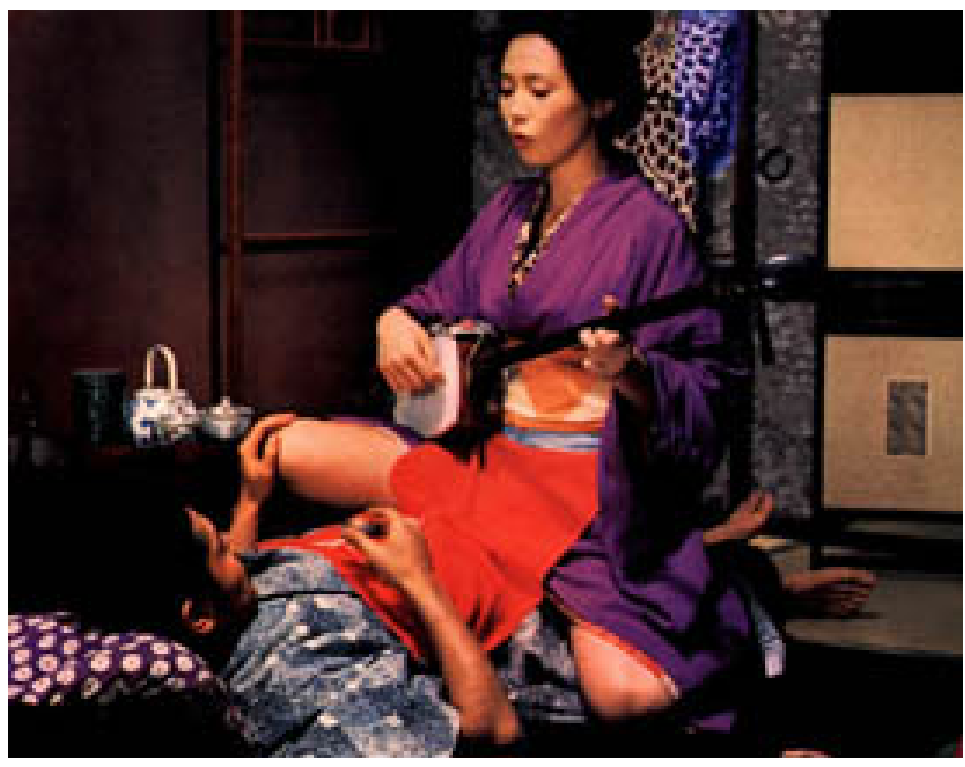

Figure 1: Empire of the Senses (Nagisa Oshima, Japan, 1976) 
Literature has been a major inspiration for sex films. In fact, the most respected film adaptations come from the writings of the great controversial "pornographic" novelists such as Junichiro Tanizaki (Daydream, The Key, Diary of a Dirty Old Man) or existentialist writers such as Kobo Abé whose allegorical Woman in the Dunes was adapted by Hiroshi Teshigahara in his cult surrealist film of the same title.

Zeng Zhuang Xiang, the Taiwan-based Hong Kong director of The Woman of Wrath, also drew heavily from the novel by Li Ang, a famous Taiwanese writer. Similarly, director Tetsuji Takechi, while working for Shochiku Studios, made his first major "pink film" based on Tanizaki's short story, Daydream, about the sexual fantasies of a young artist who, whilst under the dentist's anaesthesia, imagines a pretty girl being tortured and raped by the dentist.

This writer's encounter with Japanese "pink films" came about during last year's visit to the 12th Tokyo International Film Festival in the chance viewing of a documentary film, Ekiben (1999). The title is literally "box lunch", a slang for a standing sex position. The narrator of the film is Shungo Kaji, a veteran director of over 150 adult films and videos, who gave a terse rundown of the Japanese porn industry. He gave insider details about the Tokyo-based Nikkatsu Company, one of the most famous companies dealing in roman porno. From around 1954 onwards, they used in-house production teams to produce popular sexploitation films based on the day's trends. These ranged from youth films, romance, crime, adventure to monster movies. Like Nikkatsu, other majors such as Shochiku and Toei dabbled in sex films as they proved to be lucrative commercial productions. Nikkatsu, however, did produce some auteur and classic films, namely Seijun Suzuki's Gate of Flesh (1964) and Tetsuji Takechi's Black Snow (1965). By the early 1970s, Nikkatsu changed strategy and became controversial - via a new marketing strategy of its porn movie genre termed "roman poruno" with lurid titles such as Wet Lips, Wet Lust and Hot Skin.

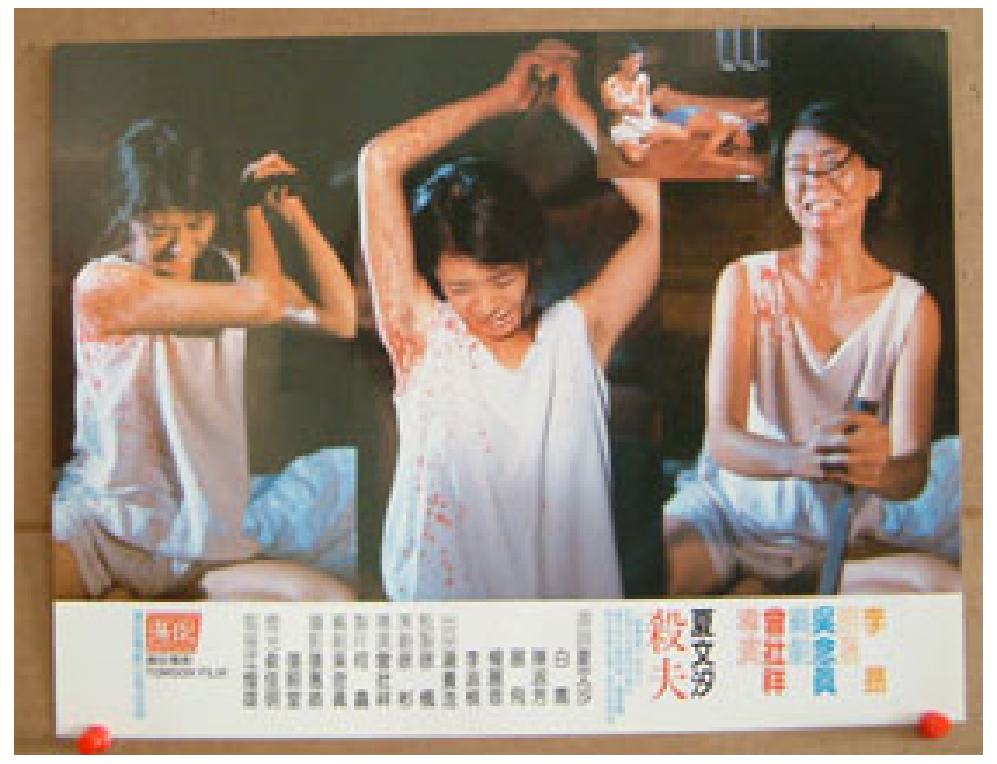

Figure 2: Woman of Wrath (Zeng Zhuang Xiang, Taiwan, 1985)

The roman poruno genre soon evolved into the arena of S \& M or sadomasochism - with titles such as Rope Slave, Slave Wife, Rope and Breasts, Female Bondage Torture and Flesh Bondage. These films featured whipping and torture, rape of repressed housewives, which continued into the 1990s with increasing intensity. These days, major Japanese cities' porn shops feature a whole series or mini-series of films with the same generic title, exploiting them for all their "erotic" worth until their staying power has been diminished and the new series starts. There are the Love Hunter (1973) trilogy, the Female Teacher 1977/83 series, the Pink Curtain 1983/ 84 series (about incest), the Zoom-up voyeurism 1981/86 series and of late, the Amateur Schoolgirl series.

Shungo contends that the roman poruno's golden age was in the 1970s, when the sexploitation movies that the major studios developed became almost an "art" form. Thus in 1971, Nikkatsu's first roman poruno 
picture was Shogoro Nishimura's Danchizuma hirusagari no joji (Apartment Wife: Affair in the Afternoon aka From Three to Sex, 1971). The story concerns an asexual husband whose wife eventually takes up a lover but a brothel's mamasan blackmails her into working for her. If not for the flourishing of the "pink films" and roman poruno, Nikkatsu would have gone under and Shungo would not have been its resident porn director of the 1990s. In fact, the whole Japanese film industry would have collapsed if not for their "erotic intrusions". A closer examination and re-appraisal of their contribution as "works of pure cinema" should yield the discovery of underrated auteurs besides Suzuki and Takechi.

The Singapore International Film Festival has selected an outstanding veteran of this genre, Tatsumi Kumashiro (1927-1995) with three of his most important works from his oeuvre of 34 films. In 1972, Kumashiro paved the way with two landmark roman poruno films: Nureta Kuchibiro and Ichijo Sayuri: Nureta Yokujo (Following Desire), made on low budgets, thus making him the Japanese Roger Corman. Like Oshima, Kumashiro's women are full of vitality and élan, while the men are romantic escapists, who get involved to ease their loneliness.

During the same period in the 1970s, the Philippines produced a somewhat similar sex genre, called "bomba" or bold films, which used female nudity or sex scenes as their selling points. This period coincided with the continuation of martial law under the then President Marcos. Along with slapstick comedies, they served as escapist distractions from the socio-political unrest and repression. The most famous landmark bomba of artistic merit was made 16 years ago. It was Tikoy Aguiluz' Boatman (1984), about the tragedy of a couple who did live sex shows but the film actually highlighted the problems of poverty, repression, crime and violence in the final years of the corrupt Marcos regime.

The 1970s and 1980s bomba era's quality outputs are few and far between. Among them: Lino Brocka's Ishmael Bernal's Manila By Night (1975) and Mister Mo, Lover Boy Ko (1974), Marilou Díaz-Abaya's Brutal (1980) and Mel Chionglo's Sinner or Saint (1984). The late Lino Brocka (1940-1991) made several significant films, including Tubog sa ginto (Dipped in Gold, 1971), Mananayaw (The Dancer, 1978) and Macho Dancer (1989). His 1975 masterpiece, Maynila sa kuko ng liwanag (Manila in The Claws of Light) is about a call boy, Julio, who leaves his village to search for his lover, Ligaya, in Manila.

Both Maynila and Macho Dancer have similar narratives and they are not gay films per se. Depending on how the viewer perceives the film, Maynila's main thrust is a tale of survival as Julio resigns himself to working as a call-boy as he continues his search for Ligaya after losing his construction job in Manila. In Macho Dancer, Pol is not gay but he becomes the lover of an American soldier after quitting school purely to get money to pay for his brother and sister. Both heroes are driven by poverty to make a living.

The major directors in the Philippines, dabbling in the bomba films, from Bernal, Brocka to Tikoy Aguiluz always worked in hidden meanings, sharply hitting out at the corrupt political status quo. For example, in Tikoy's 1996 Segurista (Dead Sure), there's very little exposure of Michelle Aldana's silk-smooth flesh - what the viewers learn in the underlying message are the evils of poverty which drive the shrewd and pragmatic woman to flee from Pinatubo's volcanic havoc, leaving her husband and child behind, while she sleeps her way to an insurance agent's dream of success.

Highlighted in the festival's programme is Jeffrey Jeturian's Fetch A Pail of Water (1999), part of the new wave of low-budget Filipino films shot on a rigorous production schedule of 21 days, inclusive of pre- and post-production. In the film, Gina, an attractive slum-girl lets her rich employer's son take sexual advantage of her. Every character in the film is faced with compromise. Even the effort of getting electricity connected becomes a body trade. Fetch A Pail Of Water is an astute, socially-concerned film, in the vein of Brocka and Bernal, but disguised as sex erotica.

The Taiwanese and the Koreans are also masters of the sex film with their "socially-concerned" erotica while their Hong Kong counterparts are more flamboyant in their portrayal of sex to keep the box-office till ringing. Taiwanese sex cinema can arguably be said to hail from a one-woman effort in the early 1980s: the well-endowed, self-taught actress Lu Xiao-fen. Before that, the golden era of Taiwanese cinema in the 1960s and 1970s was dominated by fluffy, dreamy "wen-yi" or romance films, particularly college love stories, middle-class boy-meets-girl melodramas, led by famous veterans such as Li Hsing, Song Chuen-shou and the maverick Bai Jing-rui. 


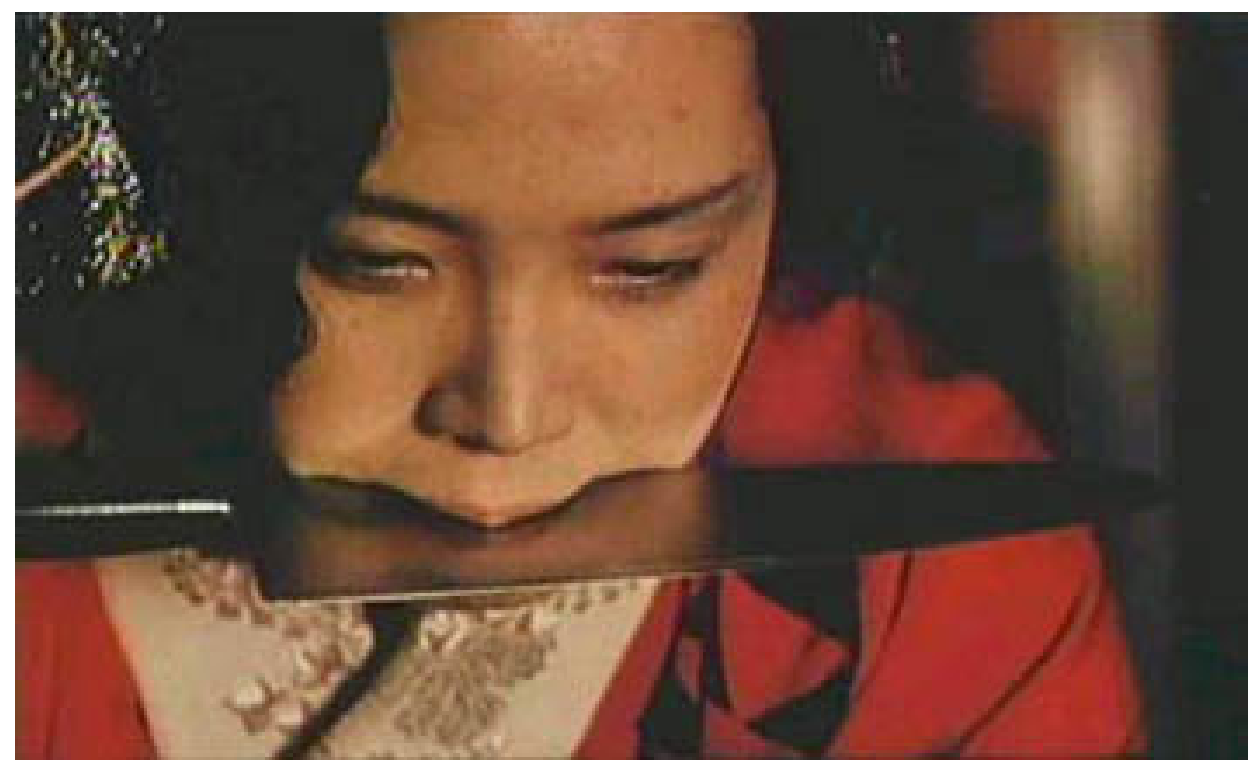

Figure 3: Empire of the Senses (Nagisa Oshima, Japan, 1976)

Lu made her reputation as Asia's answer to Marilyn Monroe when she first appeared in the shlock films of Richard Chen (of Autumn Moon fame) such as Pink Thief and Temptation as well as in the Taiwanese new wave films of the early 1980s such as Chen Kun-hou's Osmanthus Alley and Wang Tung's A Flower In the Raining Night. A veteran of some twenty films, she was most memorable in the latter social-realist film, where she plays a prostitute, Baimei. Adapted from the novelist Huang Chunming's earthy work, it is a story based on his memories of a woman he befriended and once thought of settling down with. Director Wang Tung stays faithful to Huang's rustic vision with heartfelt shots of sinewy fishermen, fish markets and backstreet scenes that paint a complex psychological landscape of the sea folks tied to their meaningless existence.

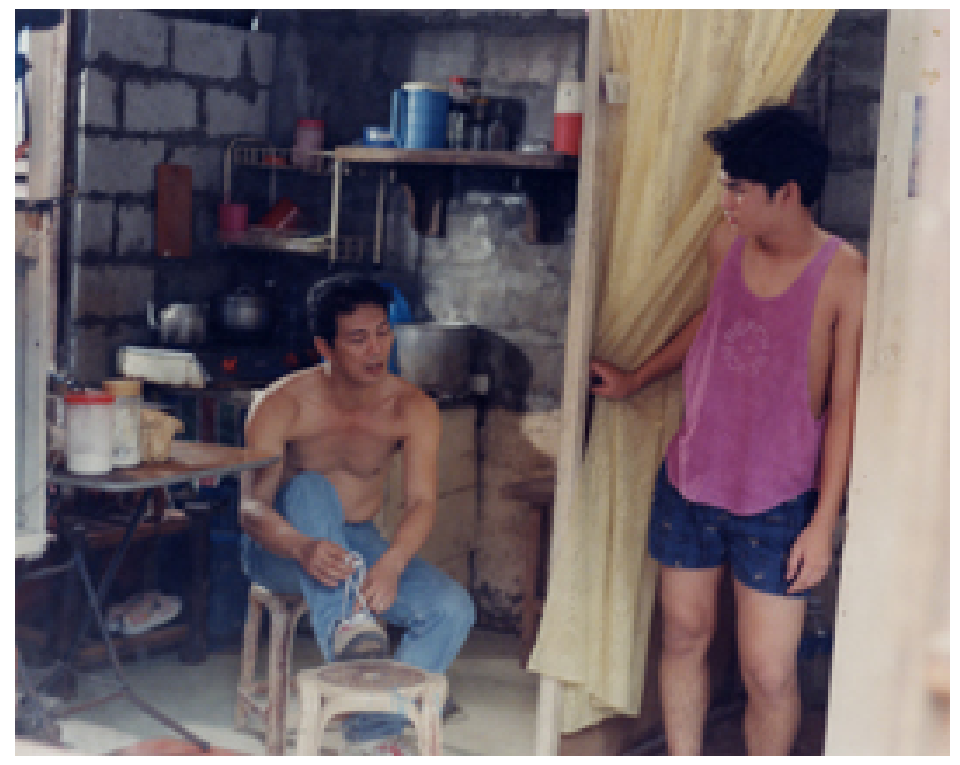

Figure 4: Fetch a Pail of Water (Jeffrey Jeturian, Philippines, 1999)

In Hong Kong, from the early 1980s till 1997, sex films helped to launch such names as Veronica Yip who 
hailed from television, former beauty queen Lily Chung Suk Wai, Pauline Chan, Isabelle Chow, Shu Qi, Amy Yip, Ewong Yung and Loletta Lee. The two major male leads were Simon Yam and Anthony Wong (who specialised in psychotic types as in The Ebola Syndrome and Untold Story). To a lesser extent, Lawrence $\mathrm{Ng}$ and Tsui Kam-guang (Viva Erotica!) gave the adult or Category III films some semblance of recognition overseas. Ewong Yung was most memorable as a rape victim in I Can't Stop This Crazy Love For You while Amy Yip was notorious for not exposing her Cup D breasts. Even in Michael Mak's cult classic Sex and Zen (1991) and Erotic Chinese Ghost Story, viewers could only catch a glimpse of her assets sideways.

The most famous adult category film star is arguably Shu Qi, who shot to critical acclaim as a film starlet in Derek Yee's Viva Erotica! She has since gone on to play more substantial character roles without disrobing. Like Shu Qi, Veronica Yip started on the road to notoriety but later showed herself to be an intelligent, though underrated actress in Stanley Kwan's Red Rose, White Rose.

Already in the 1960s, the late Kim Ki-young paved the way for Korean erotica with memorable films such as The Housemaid, (1960), Insect Woman (1972), Woman of Fire (1971), and Woman of Fire '82, where he portrayed women as sex objects and men as failures in love and sex. On the other hand, Kim's contemporary, Im Kwon-taek, looks at the hypocritical Confucianistic male order which reduces women to the level of sex objects or for producing male heirs. In his masterpiece, Surrogate Mother (1986), set towards the end of the Choson period (1392-1910), Im paints a detailed picture of a woman's individual sacrifice for the sake of the patriarchal order. In this story, Ullye, a young, naive, yet rebellious virgin from the farmer class, has an affair with a "noble" master. She bears him a child but then finds that he has abandoned her.

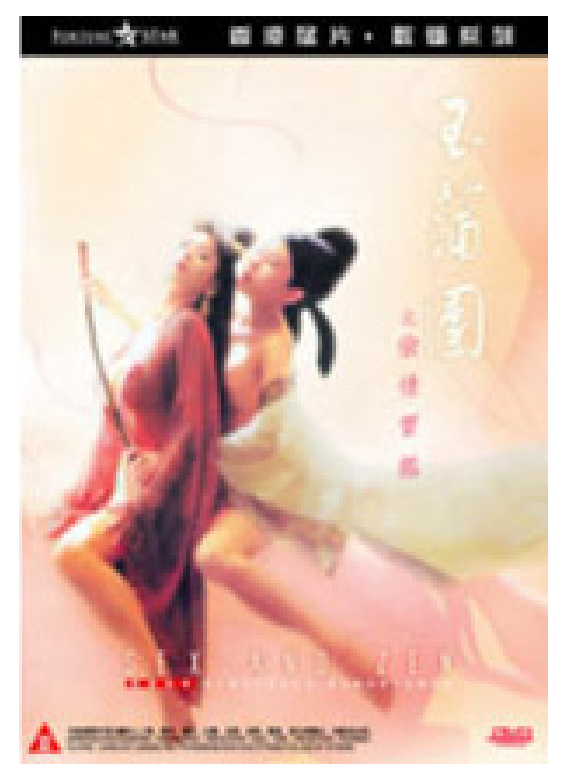

Figure 5: Sex and Zen (Michael Mak, Hong Kong, 1991)

Younger new wave filmmakers tackle the sex theme in a bolder, more experimental way. Directors such as Park Ki-yong (Motel Cactus), Jang Sun-woo (Lies, From Me To You) and Lee Myung-se (Their Last Love Affair) have been contributing interesting new works. The most controversial of them is Jang, whose latest film, Lies, has caused more than ripples and foreign sales. Lies was eventually released in January 2000 with cuts after being rejected twice by the censorship board. Production company Shin Cine and director Jang face possible prosecution on obscenity charges.

Like Oshima's Ai no corrida, Lies is about an intensely sado-masochistic relationship between a 38-year-old sculptor, J, and an 18-year-old student, Y. Their affair begins during a blind date when Y lets J make love to her in a love motel. From then on, their sexual acts become increasingly bold with acts of flagellation, first by $\mathrm{J}$ and then by Y. Even in the liberal 1990s, Lies is still shocking considering that the two protagonists are not professional actors and that the flagellation acts are real. 
Of all the established film genres, the sex category is the most powerful and it brings out the best or worst in filmmakers. With sensitive direction, these films, which on the surface, promise the depiction of flesh, really reveal our fragile human condition.

(This article is based on the author's text published in the Singapore International Film Festival 2000 Catalogue.)

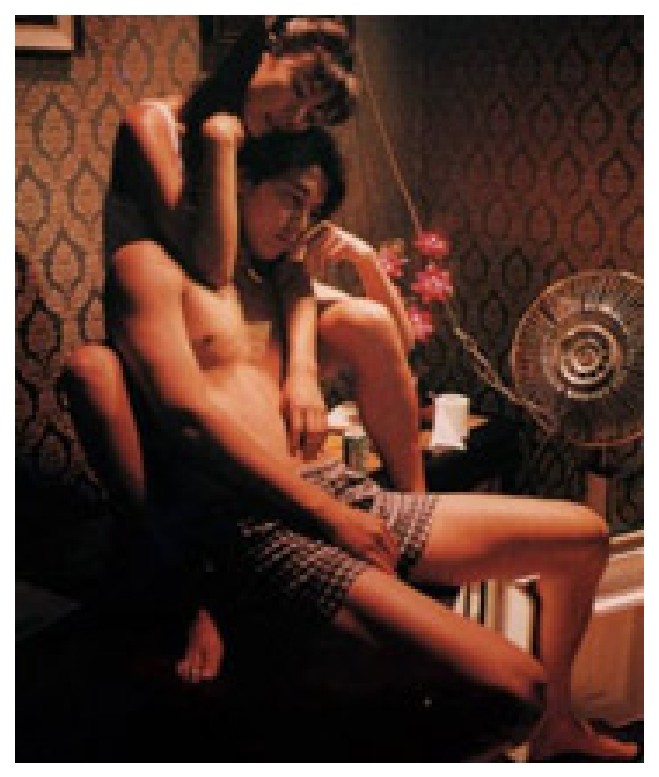

Figure 6: Motel Cactus (Park Ki-yong, Korea, 1997)

\section{Author Information}

TOH Hai Leong is a Singapore-based freelance film critic and filmmaker (Zombie Dogs, 2005) who writes for independent film publications such as Screen International and World Paper. He has covered the Hong Kong International Film Festival since 1985 and specializes in the cinemas of Hong Kong, Taiwan, China, Korea and Japan. 